\title{
НАУЧНЫЙ МИР
}

УДК 94(470.40)"1921"

\section{«НАУКА, ПРЕОБРАЗУЮЩАЯ ВЕСЬ МИР, СОЗДАЕТСЯ ГЕНИЯМИ, НУЖДАЮЩИМИСЯ В ЗАЩИТЕ И ПОМОЩИ БОЛЬШЕ, ЧЕМ КТО БЫ ТО НИ БЫЛО» (О СУДЬБАХ УЧЕНЫХ В ГОЛОДНЫЕ 1920-Е ГГ.)}

\author{
M.A. Ахметова \\ Лаборатория многофакторного гуманитарного \\ анализа и когнитивной филологии, \\ Казанский научньй центр Российской академии наук \\ Казань, Российская Федерация \\ ama201289@yandex.ru
}

Октябрьский переворот 1917 года и Гражданская война отрицательно сказались на судьбах населения страны и особенно российской интеллигенции. В голодные 1920-е годы представители ученого сословия, интеллигенции, наименее приспособленные к бедствиям, оставив научную деятельность, вынуждены были бороться за физическое выживание. Снабжение профессорско-преподавательского состава университетов продовольствием велось по остаточному принципу, и было «каплей в море». Целью статьи является раскрытие отношения власти к людям науки, а также помощи, оказанной руководством страны для облегчения участи ученых. Равнодушие власть имущих к судьбам выдающихся ученых и катастрофичность сложившейся ситуации подтверждается преждевременной смертью творцов науки, культуры на почве голода, таких как Н.Ф. Катанов, А.А. Шахматов и многих других.

Ключевые слова: голод 1921 года, Татарская АССР, академические пайки, Комиссия по улучшению быта ученых, продовольственная помощь казанской профессуре, Нансеновская помощь работникам интеллектуального труда, Дом ученых, профессиональный союз научных деятелей, Н.Ф. Катанов, А.В. Вишневский, А.А. Шахматов, В.И. Ясинский

Для цитирования: Ахметова М.А. «Наука, преобразующая весь мир, создается гениями, нуждающимися в защите и помощи больше, чем кто бы то ни было» (о судьбах ученых в голодные 1920-е гг.) // Историческая этнология. 2021. T. 6, № 2. C. 312-325. https://doi.org/10.22378/he.2021-6-2.312-325 
Ахметова M.A. «Наука, преобразующая весь мир, создается гениями, нуждающимися в защите и помощи больше, чем кто бы то ни было»...

Февральская революция 1917 г. по-своему обнадежила российскую интеллигенцию, мыслящих людей, которые увидели в ней возможности изменения и улучшения жизни, но уже октябрь-ноябрь показали, что революция - это насилие, хаос, кровь, смерть. Это сразу же проявилось во всех сферах жизни нового общества. После октябрьской революции очень сильно пострадала российская интеллигенция, поскольку ее отнесли к «классово-чуждой категории». «Наука, преобразующая весь мир, создается гениями, нуждающимися в защите и помощи больше, чем кто бы то ни было» (Уэллс 1970: 45). Эти слова английского писателя Герберта Джорджа Уэллса (1866-1946) должны были стать вехами, дать нужное направление, вектор движения для большевиков, захвативших власть в огромном государстве. Однако отношение вождя к людям науки отчетливо было выражено в письме В.И. Ленина (1919 г., 15 сентября) к Максиму Горькому, в чьей судьбе нашла глубокое отражение трагедия русской интеллигенции: «Интеллектуальные силы рабочих и крестьян растут и крепнут в борьбе за свержение буржуазии и ее пособников, интеллигентиков, лакеев капитала, мнящих себя мозгом нации. На деле это не мозг, а говно». Ориентиром стали слова В.И. Ленина, заявившего в телефонограмме М.И. Калинину и Л.Б. Красину и др. о том, что «чем больше классовых врагов унесет это бедствие, тем проще будет молодому государству» (Ленин 1965: 282). На I Всероссийском съезде учителей-интернационалистов, который прошел 5 июня 1918 г., В.И. Ленин высказал мнение, что «главная масса интеллигенции старой России оказывается прямым противником Советской власти, и нет сомнения, что нелегко будет преодолеть создаваемые этим трудности» (Ленин 1962: 420). Гибель интеллигенции была выгодна большевикам. В связи с этим скудные продовольственные запасы, имевшиеся тогда в стране, в первую очередь распределялись среди рабочих и служащих, а потом среди крестьянства (хотя оно было кормильцем и городского населения) и интеллигенции. Если бы не санкционированный грабеж населения деревни, сельские жители, скорее всего, могли бы противостоять голоду, но город сам по себе никак не мог выжить, поскольку продукты сельского хозяйства, хлеб поставлялись из деревни. Очень важно было заботиться о сельхозпроизводителях, но заботиться никто не хотел.

Профессорско-преподавательский состав вузов относился к третьей пайковой категории, их снабжение велось по остаточному принципу (Федотова, Федорова 2013: 52). При таком отношении ученые оказались на грани выживания. Вскоре после Октябрьского переворота 1917 г. начался голод. Уже в первом пореволюционном 1918 г. большевики привели великую аграрную Россию к голоду, который в той или иной степени продолжался все двадцатые и, частично, тридцатые годы. Удивителен факт, что об ученых «вспомнили» в конце 1920 г., когда в стране были введены персональные ежемесячные пайки для наиболее крупных из них. В более чем скромный паек по списку включили: мыло, 15 фунтов крупы, 45 фунтов 
хлеба, 15 фунтов селедки или мяса и 4 фунта жира (Ну, полно мне загадывать о ходе истории 1997: 91).

В «Дневниках матери-хозяйки в годы революции в России» Эмилии Бруцкус (1873-1952), жены историка народного хозяйства России Бориса Давидовича Бруцкуса (1874-1938), отразился момент, когда вместо положенной крупы в пайке давали немолотую рожь, вследствие чего жена молодого ученого П. скончалась от заворота кишок. Вот, например, как проходил обед в семье известного профессора, труды которого переведены и на европейские языки: «За столом - 6 человек, подается постный картофельный суп - по тарелке неполной и рисовый пудинг - не больше столовой ложки на каждого, хлеба за столом нет - весь за утренним чаем съеден. Прямо непонятно, зачем садятся люди за стол - разве что для возбуждения аппетита?» (Ну, полно мне загадывать о ходе истории 1997: 84).

С целью облегчения жизни ученых, угнетенных бытовыми проблемами и житейскими невзгодами не только в провинции, но и центре, правительством создавались структуры по их обеспечению. В целях сохранения научных сил, необходимых для социалистического строительства и поднятия производительности народного хозяйства и культуры, также наиболее целесообразного обеспечения нужд рабоче-крестьянской обороны Советом Народных Комиссаров 23 декабря 1919 г. был принят Декрет об улучшении положения научных специалистов. Постановлением СНК от 10 ноября 1921 г. была создана Центральная комиссия по улучшению быта ученых (ЦеКУБУ). Подобная комиссия первоначально была организована в Петрограде по инициативе М. Горького в январе 1920 г. «Петроградская комиссия по улучшению быта ученых (ПетроКУБУ)», позже в августе 1921 г. создана и Московская комиссия (МосКУБУ). В Казани Татарская комиссия по улучшению быта ученых (ТатКУБУ) была создана в феврале 1922 г., председателем которой был назначен уроженец Спасского уезда Казанской губернии, первый руководитель Народного комиссариата финансов ТАССР Александр Степанович Гордеев (1894 - после 1969).

В 1921 г. в связи с обрушившимся на Поволжье голодом после неоднократных ходатайств руководства Казанского университета в Казанский губернский продовольственный комитет и после визита представителей университета в г.Москву в г.Казани начали выдавать академический паек. В него вошли следующие продукты: 35 фунтов муки, 15 фунтов мяса, 5 фунтов рыбы, 12 фунтов крупы, 6 фунтов гороха, 4 фунта жира, 2,5 фунта сахара и 0,5 фунта кофе (ГА РТ. Ф.Р. 644: 137) с общей калорийностью 3170 (ГА РТ. Ф.Р. 644: Л. 36).

Для получения этих пайков научных работников университета распределяли на пять «продовольственных категорий» - от «начинающих молодых ученых» до «выдающихся», работа которых имела «мировое значение» (Вишленкова 2005: 278). Однако не все профессора и преподаватели получали положенные пайки. По архивным данным, в список были включены 68 профессоров и 52 преподавателя Казанского универ- 
Ахметова M.A. «Наука, преобразующая весь мир, создается гениями, нуждающимися в защите и помощи больше, чем кто бы то ни было»...

ситета, 10 профессоров и девять преподавателей Казанского политехникума, 10 профессоров и девять преподавателей Ветеринарного института, 10 профессоров и три преподавателя Восточной Академии, 16 научных работников Казанского клинического института имени В.И. Ульянова-Ленина, один научный работник Центрального музея ТАССР (Н.О. Воробьев) и восемь научных работников Педагогического института (Федотова, Федорова 2013: 191). Получающих помощь от ТатКУБУ в 1922 г. числилось 196 человек, а в 1924 г. их количество увеличилось и составляло 396 научных работников. Первые пайки были получены в 1922 г. и с 1 декабря этого г. по 1 октября 1923 г. они выдавались параллельно с нансеновскими посылками. Общее количество выделяемых пайков достигло 4557 (Федотова, Федорова 2013: 53).

Снабжение пайками учащихся и преподавателей учебных заведений в Казани началось со второй половины 1921 г., а по кантонам Татреспублики - с 1 ноября 1921 г. В первый месяц было распределено 465 преподавательских пайков среди высших учебных заведений и 535 пайков приходилось на средние и низшие профессионально-технические учебные заведения. Состав этих преподавательских пайков убогий, о питательности не может быть и речи: муки -37 фунтов, рыбы или мяса -7 фунтов, сластей - 1 фунт, соли - 2 фунта, кофе - 1/2 фунта, спичек - 2 коробки (Отчет о деятельности Татнаркомпроса 1922: 38). Всего Центром было распределено 325 преподавательских пайков по Казани и 240 пайков по кантонам.

Выдающаяся роль в деле организации бескорыстной зарубежной помощи университетам принадлежала известному норвежскому полярному исследователю, ученому-зоологу Фритьофу Нансену (1861-1930). Договор с ним о продовольственных посылках был подписан 14 ноября 1921 г., а договор о посылках профессорам - 8 июня 1922 г. (Итоги борьбы с голодом 1922: 332). Распределение продовольствия среди профессоров Казани началось еще в июне того же года и продолжалось в течение всего лета 1922 г. (хотя договор был заключен в начале июля 1922 г.), однако выдавались ли посылки позже, установить не удалось (Федотова, Федорова 2013: 141).

Нансеновская помощь работникам интеллектуального труда заключалась в выдаче посылок профессорам с марта 1922 г. по 1 июня 1923 г. В состав посылки входили следующие продукты общей массой 29 фунтов: 19 фунтов белой муки, $2 \frac{1}{2}$ фунта жиров, $2 \frac{1}{2} 2$ фунта риса, $2 \frac{1}{2}$ фунта сахаpa, 1 фунт чая, 2 банки молока (Итоги Последгол 1923: 58-59). Специальный Распределительный комитет при миссии Ф. Нансена был создан для определения наиболее нуждающихся в продовольственных пайках. Представителем комитета в Казани был доктор Э.Р. Наук, уполномоченным РСФСР при всех заграничных организациях помощи голодающим был назначен В.А. Мускат, представителем от профессуры - советский механик и математик, профессор Казанского университета Д.Н. Зейлигер, а заведующим комитета распределения посылок - Я.В. Васильев. По прото- 
колу заседания Распределительного комитета наиболее нуждающимся среди ученых были распределены посылки для 134 человек из шести учебных заведений (ГА РТ. Ф.Р. 41: Л. 15, 73). Это 10 профессоров из Восточной академии, четыре профессора из академии сельского хозяйства и лесоводства, 24 профессора из педагогического института, 26 профессоров из политехнического института, 10 профессоров из ветеринарного института и 60 профессоров Казанского университета (из них 20 - физикоматематический факультет, 15 - факультет общественных наук и 25 - медицинский факультет) (Федотова 2013: 54). А.Ю. Федотовой отмечается, что «для профессорско-преподавательского состава казанских вузов в голодные 1921-1923 гг. нансеновские посылки и академические пайки были просто «даром небес». И хотя в список вошли не все ученые Казани, для многих это было практически единственным источником средств к существованию» (Федотова 2013: 54), поскольку ученые ничего не получали от государства и остались вне поля зрения комитета Помощи голодающим.

Интеллигенция, которая могла говорить, писать и создавать интеллектуальную продукцию, не была приспособлена к таким условиям существования. Был порушен привычный ритм жизни, жуткий голод в Поволжье 1921 г. «создавал серьезную угрозу самому существованию края и даже столицы республики» (Валеев 2016: 14). Хаос в стране привел к разрушению нормального уклада жизни России, и, как справедливо отмечено М.А. Осоргиным, Россия разделилась на отдельные города, такие как Москва и Петербург, ближнюю провинцию, голодный край и т.д. «Москва живет, делает политику, пишет декреты, печатает книги, высылает изо всей России хлеб и людей, в обмен скудно посылая бумажные деньги и обильно - карательные отряды. Жизнь Москвы не имеет ничего общего с жизнью остальной бывшей России. От того, что в Саратовской губернии вымирают начисто целые уезды, московский ресторан торгует не меньше, музыка играет не печальнее. От того, что в Москве решат какой-нибудь вопрос “во всероссийском масштабе”, нигде и ничто существенно не изменится» (Осоргин 1922: 218). Множество проблем, порожденных голодом, не могло быть разрешено лишь местной республиканской властью. Отсутствие устойчивого порядка в стране, нехватка грамотных специалистов во всех органах государственной власти, апатия наркоматов в борьбе с голодом привели к небывалым потерям, и «история, если она беспристрастна, многое простит большевикам, а этого не простит» (Осоргин 1922: 224). Даже при наличии знающих руководителей автономия, разумеется, не могла самостоятельно, без указаний и помощи центральной власти, разрешить проблему голода.

В 1920-е гг. Казань, как и другие города России, стала свидетельницей поголовного бегства ученых в Петроград, Москву, Самару, Пермь, Минск и в другие города в поисках хлеба насущного и более благоприятных условий для существования. Особенно сильно пострадал университет - «рассадник науки». На страницах «Известий ТатЦИКа» (1921 г., 21 ок- 
Ахметова M.A. «Наука, преобразующая весь мир, создается гениями, нуждающимися в защите и помощи больше, чем кто бы то ни было»...

тября) преподаватель Казанского университета Б.Н. Вишневский отметил, что главным образом пустеют медицинский и естественный факультеты, наиболее важные и питающие другие факультеты (лесной и сельскохозяйственный). «Недавно медицинский факультет, - пишет он, - проводил в Петроград крупного ученого, вместе с которым уехал не менее крупный и нужный в Казани профессор-естественник» (Вишневский 1921). Установить их личности не удалось. Причина отъезда ученых в другие города заключается в отсутствии возможностей для обеспечения себя и своих семей продовольствием и дровами (многие обитали в лабораториях, где комнатная температура поддерживалась газом во время огневых работ). Бытовые проблемы, борьба за физическое выживание не дали возможности продолжить учебные занятия, наука отошла на второй план.

Среди ученых были и такие, кто отказывался уезжать из Казани. Например, советский хирург, создатель знаменитой лечебной мази «Линимент бальзамический по Вишневскому», руководивший в голодные годы областной больницей Татарской АССР, Александр Васильевич Вишневский (1874-1948) отчаянно боролся с эпидемией сыпного тифа и, несмотря на бытовые трудности и отсутствие продовольствия, не мог оставить больных. Однако не всем удалось пережить это страшное время. За первые три месяца 1921 г. в Казани скончались восемь ученых (ГА РТ. Ф.Р. 1337: Л. 1, 11). Некоторые из них: профессор кафедры русской истории П.Г. Архангельский (05.01.1921 г.), профессор кафедры социологии В.К. Соколов (07.03.1921 г.), профессор кафедры славянской филологии Н.М. Петровский (06.02.1921 г.), профессор кафедры теории капиталистического хозяйства П.А. Никольский (18.01.1921г.), профессор кафедры гистологии Д.А. Тимофеев (28.02.1921 г.), профессор краеведения Восточного института народного образования И.В. Тюшняков (17.03.1921 г.), Клепцов и др. Официальный орган ТАССР «Известия ТатЦИКа» сообщал о кончине мастера-гравера второй государственной типо-литографии (быв. «Умид») Татреспублики Прокопия Александровича Зверева (19.11.1921г.), преподавательницы Рабочего факультета Казанского государственного университета Марии Павловны Ветохиной (08.12.1921 г.), учительницы школы І ступени № 20 Веры Николаевны Абакумовой (30.12.1921 г.), профессора Клинического института Александра Арефьевича Хитрово (18.01.1922 г.), профессора Ветеринарного института Карла Матвеевича Гольцмана (03.02.1922 г.), преподавателя Рабфака Академии Хасана Султановича Султанова (06.02.1922 г.), помощника директора восточной консерватории, заведующего художественным комитетом академического центра НКПР ТАССР Абдеррахмана Хайрулловича Симакова (21.03.1922 г.).

Научным отделом Народного комиссариата просвещения ТАССР и научной секцией Союза работников просвещения был поднят вопрос о необходимости создания «Дома ученых» по примеру Петрограда, Москвы и некоторых провинциальных городов. В Петрограде «Дом ученых» был создан 31 января 1920 г. по инициативе председателя Петроградской ко- 
миссии по улучшению быта ученых М. Горького. Кроме «Дома ученых» были общежитие, санаторий для ученых-дистрофиков, амбулатория, баня, мастерские (Таганцев 1998: 130). Преподавателем Казанского университета Б.Н. Вишневским на страницах «Известия ТатЦИКа» был поднят вопрос о создании «Дома ученых» и Дома-общежития с рядом вспомогательных учреждений (столовой, прачечной, парикмахерской, сапожной мастерской и т.д.) с целью остановить бегство ученых из Казани и наладить правильную работу высшей школы (Вишневский 1921).

Критико-библиографический журнал «Казанский библиофил», показывает, насколько ужасной была обстановка в Казани для великих ученых. 10 марта 1922 г., в час ночи, русская наука лишилась выдающегося ученого, профессора Казанского университета, Восточной консерватории, Восточной академии, действительного члена Общества археологии, истории и этнографии и члена русских и многих заграничных ученых обществ, заведующего Казанским городским музеем (Центральным музеем Татреспублики) Николая Федоровича Катанова (1862-1922). В некрологе профессора на последней странице журнала «Казанский библиофил» отмечается, что «с осени 1921 г. профессора Катанова постиг удар паралича, после которого он стал уже оправляться. Но простуда сделала свое дело в ослабевшем от недостаточного питания организме. Развился гнойный плеврит. Была сделана операция. Однако операция оказалась бесполезной. Крупный ученый, с мировой известностью навеки закрыл глаза от полуголодной жизни, оставив после себя обширное литературное наследие и необеспеченную семью» (Казанский библиофил 1921). Эта цитата показывает всю катастрофичность ситуации в Татреспублике. Благороднейший, фантастической эрудиции человек, ученый-полиглот Н.Ф. Катанов, владевший более чем двадцатью языками, имевший большую семью, не мог обеспечить ее питанием и умер от голода. Чрезвычайно скромный и миролюбивый Н.Ф. Катанов, как свидетельствует газета «Известия ТатЦИКа», живя в условиях тяжелой материальной нужды, никогда не жаловался на свою судьбу, наоборот, можно было подумать, видя его всегда спокойное лицо, что ему живется очень хорошо (Известия ТатЦИКа 1922).

Начиная с 1894 г. деятельность Н.Ф. Катанова была связана с Казанью, хотя его приглашали в другие города, обещали создать более благоприятные условия для дальнейшей работы и обеспеченную жизнь, чем в Татреспублике. Если бы Н.Ф. Катанов решился уехать в голодные 19201921 гг. в Красноярск ли, Владивосток ли, Ташкент ли или Баку, не пришлось бы теперь оплакивать его безвременную кончину. В голодные и холодные годы, когда к умственному труду добавились и физические нагрузки (таскать воду, колоть дрова, простаивать целые часы в очередях, работать и целые ночи дежурить на огороде), его достаточно сильный организм не выдержал, и «могила его долго будет служить укором его современникам, не сумевшим в Татреспублике уберечь такого исключитель- 
Ахметова M.A. «Наука, преобразующая весь мир, создается гениями, нуждающимися в защите и помощи больше, чем кто бы то ни было»...

ного по дарованиям, познаниям, особенно в области тюркских наречий, и редким душевным качествам человека» (Харлампович 1922: 195).

После смерти Н.Ф. Катанова на страницах газеты «Известия ТатЦИКа» появляется статья Г.С. Серебрянникова «Профессор Катанов и “усиленная пенсия"» (1922 г., 26 марта). Автор ищет ответ на вопрос, почему Союз не использует средств Народного Комиссариата социального обеспечения Татреспублики по инструкции Народного Комиссариата Социального Обеспечения РСФСР от 5 декабря 1921 г. об усиленных пенсиях. Согласно данной инструкции она назначается в случае полной утраты трудоспособности лицам, имеющим крупные заслуги по революционной деятельности, выдающимся научным работникам, активным участникам революционного и профессионального движений и тем, кто своим участием в местной работе существенно усилили советскую власть, а также тем из деятелей науки, искусства, литературы, здравоохранения и техники, которые своими трудами в соответствующей области внесли ценный вклад в общечеловеческую или отечественную культуру. В случае смерти лиц, имевших эти заслуги, пенсия выдается нетрудоспособным, находившимся на их иждивении членам семьи. Для руководства республики и страны на первом месте стояли революционные деятели, поэтому крупнейший востоковед страны Н.Ф. Катанов просто угасал. Получал ли он усиленную пенсию, неизвестно. Если даже и получал, то частично, с перерывами, поскольку даже «те меры пайкового обеспечения, которые благодаря заботам Совнаркома ТАССР должны были пройти в жизнь, на самом деле осуществлены только наполовину и недоданное ничем не компенсировано» (Вишневский 1921). Смерть Катанова - это было «безумное убийство, совершенное на глазах у всех». Именно такими словами историкславист, археограф Н.К. Никольский, который сам перенес сыпной тиф, оценил безвременную кончину другого выдающего ученого-языковеда, исследователя рукописей Алексея Александровича Шахматова (18641920). Он скончался 16 августа 1920 г., оставив после себя большую семью из шести детей. Его неожиданная и трагическая смерть, как пишет один из его последних учеников В.В. Виноградов, «одно из самых печальных следствий «смутного» времени. В годы культурного распада А.А. Шахматову приходилось совмещать с разносторонней научно-исследовательской и организаторской работой непосильный физический труд. Организм, надломленный нуждой и голодом, не выдержал. Развилась тяжелая болезнь, и 16 августа 1920 г. после операции А.А. умер» (Виноградов 1922: 28).

Смерть А.А. Шахматова от истощения организма длительными голодовками, как считает литературовед-славист Владимир Николаевич Перетц, - «самый суровый приговор тем, кто допустил такое преступление против культуры и науки». Уже осенью 1918 г. он в своих письмах знаменитому юристу, судье, государственному и общественному деятелю, литератору Анатолию Федоровичу Кони (1844-1927) жаловался на тяжелое 
продовольственное положение, изнуряющие домашние хлопоты: доставку и расколку дров, топку печи в ущерб научным занятиям. Продовольственное положение усложнялось с каждым днем (не по дням, а по часам, как писал филолог-славист А.И. Соболевский), и ухудшение материального, морального и физического положения А.А. Шахматова продолжалось в последующие годы. От сыпного тифа умирает его сестра, от голода ослабли жена и младшая дочь (Робинсон 2004: 79). Он был в тревоге за свое семейство, но старался не опускать руки и, как настоящий ученый, спасение искал в науке. Сила воли человека, который, даже умирая от истощения, продолжал работать над вопросами синтаксиса русского языка, вызывает восхищение. Семья его терпела нужду, поскольку он получал всего лишь один паек на большое семейство, при этом сам Шахматов старался вести хозяйственные работы. Его товарищи, друзья, ученики и коллеги считали истинными виновниками безвременной кончины ученого власть.

Борьба за физическое выживание, житейские заботы, чрезвычайно сложное материальное положение и отсутствие продовольствия у ученых начались уже в конце 1917 - в начале 1918 г. Первые признаки приближающегося голода в городах появились в 1917 г., а в 1919-1921 гг. голод безжалостно уничтожил много талантливых людей, известных ученых. В историографии принято считать голодными 1921-1922 гг., хотя это сужает временные рамки голода. Сразу после октябрьского переворота на страну обрушился продовольственный кризис, голод стремительно охватывал города и регионы. Интеллигенция была особенно не приспособлена к жизни. Многие ее представители выменивали на хлеб свое последнее имущество. Драгоценности, одежда, книги отдавались за бесценок, лишь бы как-то прокормить свои семьи. Многие, бросив свои «насиженные гнезда», уезжали в поисках лучшей доли: кто на шахты, кто держали путь на юг. В результате республика в эти годы потеряла сотни тысяч людей.

В южных городах в голодные годы дороговизна муки и хлеба превзошла казанские цены: один фунт самого плохого хлеба стоил 85-100 тысяч рублей. Об этом свидетельствует письмо Б.М. Ляпунова академику В.М. Истрину от 26 апреля 1922 г. Неустойчивая государственная поддержка в виде пайков (то полное отсутствие, то временное приостановление) и отсутствие других видов помощи привели к полунищенскому существованию. Письмо Ляпунова свидетельствует о том, что и в Одессе не было спасения от голода: «Приходится или продавать все самое ценное за бесценок, как делали это мы, или обращаться в Комитет Содействия ученым, оттуда помощь приходит тоже нескоро и в очень ограниченном количестве. Много оказывает поддержки A.R.A, но ее “посылки” очень ограничены количеством и в первые очереди достались больным и обремененным семьями. Нам удалось после многих мытарств получить посылку во вторую очередь от Общества помощи литераторам и ученым, но большинство профессоров еще ждут, голодают и крайне бедствуют» (Робинсон 2004: 111). 
Ахметова M.A. «Наука, преобразующая весь мир, создается гениями, нуждающимися в защите и помощи больше, чем кто бы то ни было»...

В тяжелые голодные годы общими усилиями профессоров, особенно Московского университета, в Москве был создан профессиональный союз научных деятелей. В его организации важную роль сыграл профессор Императорского технического училища Всеволод Иванович Ясинский (18841933), участвовавший в работе комитета Всероссийской помощи голодающим. Он возглавил союз. Деятельность этого профессионального союза распространялась за пределы профессиональных нужд и стала «настоящим бельмом на глазу у Комиссариата народного просвещения». После непрерывной борьбы союз был закрыт. Как сообщает русскоязычная газета, «Последние новости», издававшаяся в Париже (1933 г., 23 декабря), вместо него, после нескольких переходных преобразований, образовалась Комиссия по улучшению быта ученых (КУБУ), фактическим руководителем которой стал тот же В.И. Ясинский. Благодаря неутомимому руководителю, как пишет профессор Московского государственного университета В.В. Стратонов (Стратонов 1933), академические пайки перешли в ведение КУБУ и несколько десятков тысяч ученых стали сноснее питаться (количество научных деятелей в Москве, не учитывая деятелей литературы и искусств, превышало семь тысяч). Ранее академические пайки для деятелей науки выдавались из советских продовольственных распределителей, где беспощадно обкрадывали и обвешивали ученых. Благодаря В.И. Ясинскому был разрешен и жилищный вопрос. Он добился создания при КУБУ жилищного товарищества, в распоряжение которого было получено 11 многоэтажных домов для научных деятелей в разных районах Москвы. Он постоянно «вырывал» у представителей советской власти дрова и торф для облегчения обострившейся материальной нужды ученых. В.И. Ясинский, проявивший «незаурядную самодеятельность и мужество в отстаивании интересов московских ученых перед большевицкой властью» (Некрологи В.И. Ясинского 1933), в 1922 г. был выслан в Берлин.

Первая партия ученых из 120 российских мыслителей была изгнана за рубеж 22 сентября 1922 г. В список была включена профессура Первого Московского университета, Петровско-Разумовской сельскохозяйственной академии, Института инженеров путей сообщения. Расширился список фигурантами «по делу Вольно-экономического общества», «Списком антисоветских профессоров Археологического института», «Общим списком активных антисоветских деятелей по делу издательства «Берег», «Списком лиц, проходящих по делу № 813 (группа Абрикосова)», «Списком антисоветских агрономов и кооператоров», «Списком врачей», «Списком антисоветских инженеров», «Списком литераторов», «Списком питерских литераторов» и специальным «Списком антисоветской интеллигенции г. Петрограда» (Волкогонов 1994: 180-181). В 1920-е гг. при новом режиме, как пишет В.В. Стратонов, декан физико-математического факультета МГУ, грубо стали уничтожаться культурные силы, нависла угроза над учеными. Всеволод Викторович Стратонов (1869-1938) вместе с группой ученых в 1922 г. был выслан из СССР, последние годы жизни 
провел в Праге. В октябре 1922 г. был выслан из РСФСР в Берлин и заместитель декана историко-филологического факультета Казанского университета, историк Иринарх Аркадьевич Стратонов (1881-1945). «За рубеж в ходе гражданской войны ушла лавина интеллигенции, вернулись тоненькие ручейки... да остались еще те, “почему-либо не расстрелянные"» (Волкогонов 1994: 191).

В новой постреволюционной действительности ученым не нашлось места. «К людям науки, первое время, советское правительство питало столь же мало уважения, как и первая французская революция, которая "не нуждалась в химиках". Этот класс работников, жизненно необходимых для всякого культурного государства, был таким образом доведен до состояния самой крайней нужды и нищеты... Смертность среди умственно выдающихся людей в России огромна. Многие смерти, конечно, были вызваны тяжелыми условиями жизни, но в большинстве случаев, я думаю, причиной смерти послужил душевный гнет, разочарование - когда выдающиеся способности оказались лишними и ненужными» (Уэллс 1921: 26). Чтобы спасти себя, семью и своих детей от голодной смерти ученым приходилось бороться за выживание, заменять создание интеллектуальных продуктов на каждодневный физический труд. Муки и ужасы пережитых дней, страдание народа и русской интеллигенции во время голода 1921 г. отражаются в публицистике М. Горького: «...Люди, которые лишь недавно обладали способностью жить культурными интересами, были в полном расцвете умственных сил, - поглощены сейчас исключительно борьбой за хлеб насущный, - это зрелище очень печальное!» (Горький 1954: 416). Приведенные документальные свидетельства, фрагменты воспоминаний деятелей науки наглядно подтверждают факт равнодушия советской власти к судьбам выдающихся ученых того времени.

\section{ИСТОЧНИКИ И МАТЕРИАЛЫ}

Ну, полно мне загадывать о ходе истории 1997 - «Ну, полно мне загадывать о ходе истории...» (Из «Дневника матери-хозяйки в годы революции в России») / Сост. Н.Л. Рогалина, В.Л. Телицын // Отечественная история. 1997. № 3. С. 80-95.

Виноградов 1922 - Виноградов В.В. Алексей Александрович Шахматов. Петербург: Колос, 1922.80 с.

Вишневский 1921 - Вишневский Б.Н. Судьба науки в Казани и «Дом ученых» // Известия ТатЦИКа. 1921. 21 октября.

Волкогонов 1994 - Волкогонов Д. Ленин. Политический портрет: в 2-х кн. М.: Новости, 1994. Кн. 2.

Горький 1954 - Горький М. Собрание сочинений: в 30 тт. М.: Гос. изд-во худож. лит., 1954. Т. 29: Письма, телеграммы, надписи (1907-1926).

ГА РТ. Ф.Р. 41 - Государственный архив Республики Татарстан. Ф.Р. 41. Оп. 1. Д. 63. 
Ахметова M.A. «Наука, преобразующая весь мир, создается гениями, нуждающимися в защите и помощи больше, чем кто бы то ни было»...

ГА РТ. Ф.Р. 1337 - Государственный архив Республики Татарстан. Ф.Р. 1337. Оп. 1. Д. 49.

ГА РТ. Ф.Р. 644 - Государственный архив Республики Татарстан. Ф.Р. 644. Оп. 1. Д. 99.

Известия ТатЦИКа 1922 - Известия ТатЦИКа. 1922. 11 марта.

Итоги борьбы с голодом 1922 - Итоги борьбы с голодом в 1921-1922 гг.: сборник статей и отчетов. М.: Издание ЦК Помгол, 1922.

Итоги Последгол 1923 - Итоги Последгол (с 15/ X-1922 г. - 1/ VIII-1923 г.): сборник статей и материалов. М.: Изд. Ликвидкома ЦКПГ ВЦИК, 1923.

Казанский библиофил 1921 - Казанский библиофил. 1921. № 2.

Ленин 1962 - Ленин В.И. Полное собрание сочинений. М.: Госиздат политической литературы, 1962. Т. 36: Март - июль 1918 г.

Ленин 1965 - Ленин В.И. Полное собрание сочинений. М.: Госиздат политической литературы, 1965. Т. 53: Письма. Июнь - ноябрь 1921 г.

Некрологи В.И. Ясинского 1933 - Некрологи В.И. Ясинского, опубликованные в эмигрантских изданиях // Возрождение (Париж). 1933. 17 ноября.

Осоргин 1922 - Осоргин М.А. Тем же морем // Современные записки. 1922. № XIII. C. 214-227.

Отчет о деятельности Татнаркомпроса 1922 - Отчет о деятельности Татнаркомпроса за время с последнего Всетатарского съезда Советов по 1-е октября 1922 г. Казань: Издание Татнаркомпроса, 1922.

Стратонов 1933 - Стратонов В.В. Памяти В.И. Ясинского // Последние новости. 1933. 23 декабря.

Таганцев 1998 - Таганцев Н.С. Дневник 1920-1921 гг. / публ. К.В. Таганцева; подгот. текста Н.Б. Орловой-Вальской; коммент. В.Ю. Черняева // Звезда. 1998. № 9. С. 130-157.

Уэллс 1970 - Уэллс Г. Россия во мгле / пер. с англ.; предисловие акад. И.М. Майского. М.: Прогресс, 1970.

Уэллс 1921 - Уэльс Г. Россия во мгле / пер. с англ.; с предисловием кн. Н.С. Трубецкого. София: Российско-болгарское книгоиздательство, 1921.

Харлампович 1922 - Харлампович К. Профессор Н.Ф. Катанов (некролог) // Казанский музейный вестник. Казань, 1922. № 1. С. 187-195.

\section{НАУЧНАЯ ЛИТЕРАТУРА}

Валеев Н.М. Константин Чеботарев, Александра Платунова. В поисках пути в искусстве. Казань: Заман, 2016.

Вишленкова E.A. Terra Universitatis: Два века университетской культуры в Казани / Е.А. Вишленкова, С.Ю. Малышева, А.А. Сальникова. Казань: КГУ им. В.И. Ульянова-Ленина, 2005.

Робинсон М.А. Судьбы академической элиты: отечественное славяноведение (1917 - нач. 1930-х гг.). М.: Индрик, 2004.

Федотова А.Ю. Продовольственная помощь казанской профессуре в условиях голода 1921-1923 гг. // Гасырлар авазы - Эхо веков. 2013. № 3/4. С. 53-60.

Федотова А.Ю., Федорова Н.А. Помощь голодающему населению ТАССР советскими и иностранными организациями в 1921-1923 гг. Казань: ИИЦ УДП PT, 2013. 
Сведения об авторе: Ахметова Миляуша Ансаровна - кандидат филологических наук, старший научный сотрудник Лаборатории многофакторного гуманитарного анализа и когнитивной филологии Федерального исследовательского центра «Казанский научный центр Российской академии наук» (420111, ул. Лобачевского, 2/31, Казань, Российская Федерация); ama201289@yandex.ru

Поступила 14.01.2021

Принята к публикации 22.11.2021

Опубликована 29.11.2021

\title{
"SCIENCE TRANSFORMING THE WORLD IS CREATED BY GENIUSES IN NEED OF PROTECTION AND ASSISTANCE MORE THAN ANYONE" (ON THE FATE OF SCIENTISTS IN THE FAMINE OF 1920s)
}

\author{
M.A. Akhmetova \\ Laboratory of the Multiple-factor Humanitarian \\ Analysis and Cognitive Philology, \\ Kazan Scientific Center of the Russian Academy of Sciences \\ Kazan, Russian Federation \\ ama201289@yandex.ru
}

The October coup of 1917 and the Civil War negatively affected the fate of the country's population, particularly the Russian intellectuals. Representatives of the academic class, intellectuals, who are least adapted to disasters, had to fight for physical survival having left scientific work. The supply of food to university professors was carried out on a residual basis and was a "drop in the sea." The purpose of the article is to reveal the attitude of the leader towards the people of science, as well as the assistance provided by the republican power to alleviate the fate of Kazan scientists. Documentary evidence suggests that the government was indifferent to the fate of outstanding scientists. The catastrophic situation in the Tatar Republic is confirmed by the premature death of creators of science and culture such as N.F. Katanov, A.A. Shakhmatov and many other professors of Kazan universities due to the hunger.

Keywords: famine of the 20th century, Tatar Republic, academic rations, Commission for the Improvement of the Life of Scientists, food assistance to the Kazan professorship, Nansen assistance to intellectual workers, Center for science, professional union for scientists, N.F. Katanov, A.V. Vishnevskiy, A.A. Shakhmatov, V.I. Yasinskiy

For citation: Akhmetova M.A. «Nauka, preobrazuyushhaya ves` mir, sozdaetsya geniyami, nuzhdayushimisya $\mathrm{v}$ zashhite i pomoshhi bol'she, chem kto by' to ni by'lo» (o sud'bax ucheny`x v golodny`e 1920-e gg.) ["Science Transforming the World is Created by Geniuses in Need of Protection and Assistance More than Anyone." (On the Fate of Scientists in the Famine of 1920s)] // Istoricheskaya etnologiya, 2021, vol. 6, no. 2, pp. 312-325. https://doi.org/10.22378/he.2021-6-2.312-325 
Ахметова M.A. «Наука, преобразующая весь мир, создается гениями, нуждающимися в защите и помощи больше, чем кто бы то ни было»...

\section{REFERENCES}

Valeev N.M. Konstantin Chebotarev, Aleksandra Platunova. V poiskakh puti $v$ iskusstve [Konstantin Chebotarev, Aleksandra Platunova. In Search of a Way in Art]. Kazan: Zaman, 2016. (In Russian)

Vishlenkova E.A., Malysheva S.Yu., Sal'nikova A.A. Terra Universitatis: Dva veka universitetskoy kul'tury v Kazani [Terra Universitatis: Two Centuries of University Culture in Kazan]. Kazan: V.I. Ulianov-Lenin Kazan State University Publ., 2005. (In Russian)

Robinson M.A. Sud'by akademicheskoy elity: otechestvennoe slavianovedenie (1917 - nachalo 1930-kh godov). [The Fate of Academic Elite: Russian Slavic studies (1917 - early 1930s]. Moscow: Indrik Publ., 2004. (In Russian)

Fedotova A. Prodovol'stvennaya pomoshch' kazanskoy professure v usloviiakh goloda 1921-1923 gg. [Food Aid to Kazan Professors in the Conditions of Famine]. Gasyrlar avazy - Ekho vekov, 2013, no. 3/4, p. 53-60. (In Russian)

Fedotova A.Yu., Fedorova N.A. Pomoshch' golodayushchemu naseleniyu TASSR sovetskimi i inostrannymi organizatsiyami v 1921-1923 gg. [Aid to the Starving Population of the TASSR by Soviet and Foreign Organizations in 1921-1923]. Kazan: IITS RT UDP Publ., 2013. (In Russian)

About the author: Milyausha A. Akhmetova, Cand. Sc. (Philology), Senior Research Fellow of the Laboratory of the Multiple-factor Humanitarian Analysis and Cognitive Philology, Kazan Scientific Center of the Russian Academy of Sciences (2/31 Lobachevskiy St., Kazan 420111, Russia); ama201289@yandex.ru 